\title{
Effect of adding cofactors to exogenous fibrolytic enzymes on preingestive hydrolysis, in vitro digestibility, and fermentation of bermudagrass haylage
}

\author{
J. J. Romero, ${ }^{* 1}$ Z. X. Ma, ${ }^{*}$ C. F. Gonzalez,† and A. T. Adesogan ${ }^{* 2}$ \\ ${ }^{*}$ Department of Animal Sciences, and \\ †Department of Microbiology and Cell Science, Institute of Food and Agricultural Sciences, University of Florida, Gainesville 32608
}

\begin{abstract}
Our objectives were to examine if adding metal ion cofactors $(\mathrm{COF})$ to exogenous fibrolytic enzymes (EFE) would increase the beneficial effects of the EFE on the preingestive hydrolysis and in vitro digestibility and fermentation of bermudagrass haylage. In experiment 1,5 $\mathrm{COF}\left(\mathrm{Mn}^{2+}, \mathrm{Co}^{2+}, \mathrm{Fe}^{2+}, \mathrm{Ca}^{2+}\right.$, and $\left.\mathrm{Mg}^{2+}\right)$ were screened to select the best candidates for synergistically enhancing release of water-soluble carbohydrates (WSC) from bermudagrass haylage by $5 \mathrm{EFE}$. The $5 \mathrm{EFE}$ (1A, 2A, 11C, 13D, and 15D) were sourced from Trichoderma reesei and Aspergillus oryzae and they were the most effective of $12 \mathrm{EFE}$ at increasing the neutral detergent fiber digestibility of bermudagrass haylage in a previous trial. Adding $1 \mathrm{mM}$ of each of the COF to EFE 2A or $11 \mathrm{C}$ synergistically increased release of WSC from bermudagrass haylage, as did adding $\left(1 \mathrm{mM}^{2} \mathrm{Fe}^{2+}\right.$ to $1 \mathrm{~A}, \mathrm{Mn}^{2+}, \mathrm{Co}^{2+}$, or $\mathrm{Fe}^{2+}$ to $13 \mathrm{D}$, or $\mathrm{Co}^{2+}$ or $\mathrm{Fe}^{2+}$ to $15 \mathrm{D}$. The greatest release of WSC responses were obtained by adding $\mathrm{Mn}^{2+}$ to $11 \mathrm{C}(38 \%)$ or by adding $\mathrm{Fe}^{2+}$ to $2 \mathrm{~A}$ or $13 \mathrm{D}$ (10 and $21.9 \%$, respectively). In experiment 2 , the effect of increasing the $\mathrm{COF}$ dose on in vitro digestibility and fermentation of bermudagrass haylage was examined using the best EFE-COF combinations from experiment 1. Effects of adding increasing doses of these $\mathrm{COF}$ on EFE-mediated changes in vitro digestibility depended on the COF-EFE combination.

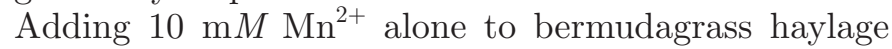
increased DMD and NDFD by 2.7 and $6.3 \%$ and adding $11 \mathrm{C}$ alone increased these measures by 6.6 and $15.5 \%$, respectively. However, adding $10 \mathrm{mM} \mathrm{Mn^{2+ }}$ with $11 \mathrm{C}$ resulted in 3.5 and $8.1 \%$ increases in DMD and NDFD, respectively, beyond the increases caused by adding $11 \mathrm{C}$ alone. Adding $\mathrm{Fe}^{2+}$ to $2 \mathrm{~A}$ had no effects on EFEmediated digestibility responses, but $2 \mathrm{~A}$ prevented adverse effects of adding $\mathrm{Fe}^{2+}$ alone on DMD and NDFD. In contrast, adding $\mathrm{Fe}^{2+}$ to $13 \mathrm{D}$ reduced the increases
\end{abstract}

Received September 12, 2014.

Accepted March 20, 2015.

${ }^{1}$ Current address: North Carolina State University, Department of Crop Science, Raleigh, 1104A Williams Hall, Raleigh, NC 27695-7620.

${ }^{2}$ Corresponding author: adesogan@ufl.edu in DMD and NDFD caused by adding the EFE alone. This study shows that adding COF to EFE can synergistically increase, decrease, or not affect the hydrolytic effects of EFE on bermudagrass haylage cell walls. The outcome depends on the specific EFE-COF combination and the COF dose. More research is required to understand the mechanisms resulting in these outcomes to exploit beneficial effects of COF on EFE.

Key words: fibrolytic enzyme, dairy cattle, bermudagrass, cofactor

\section{INTRODUCTION}

Exogenous fibrolytic enzymes (EFE) have been applied to dairy cattle diets to improve animal performance because of their ability to catalyze the depolymerization of forage fiber, which is the main barrier to nutrient availability (Meale et al., 2014). However, the results of EFE application in the literature have been equivocal (Beauchemin and Holtshausen, 2010; Adesogan et al., 2014). This is because the outcome is influenced by numerous factors including the EFE dose (Eun et al., 2007) and activity composition (Eun and Beauchemin, 2007), the prevailing $\mathrm{pH}$ and temperature (Arriola et al., 2011), the animal performance level (Schingoethe et al., 1999), the experimental design (Adesogan et al., 2014), and the fraction and proportion of the diet to which the EFE is applied (Krueger et al., 2008; Dean et al., 2013). Despite their well-known effects on the activity of certain enzymes (Voet et al., 2010), effects of metal ion cofactor (COF) addition to $\mathrm{EFE}$ on the digestibility of forages are unknown. Metalactivated enzymes and metalloenzymes use COF for structural and catalytical roles, respectively (Voet et al., 2010). Metal-activated enzymes require COF for maximal activity because they improve the conformational stability of the enzymes, but the COF are not direct components of the enzyme reaction mechanism (Glusker, 2011). Consequently, metal-activated enzymes can function without COF at a reduced activity level (Glusker, 2011). Whereas metalloenzymes require $\mathrm{COF}$ at their active sites to function because they serve as substrate templates, inducers of free radicals, and 
redox-active COF (Purich, 2011). Among enzymes involved in lignocellulose degradation, only a few, mostly those grouped in the auxiliary activities family, have been identified as metalloenzymes (Harris et al., 2010; CAZy, 2013). Metal ion cofactors such as $\mathrm{Mn}^{2+}, \mathrm{Co}^{2+}$, $\mathrm{Fe}^{2+}, \mathrm{Ca}^{2+}$, and $\mathrm{Mg}^{2+}$ have increased the activity of metal-activated fibrolytic enzymes (BRENDA, 2013), but to our knowledge their effects on EFE used in ruminant nutrition have not been examined.

The productivity of dairy cattle in the southeastern United States is limited by the low digestibility of tropical grasses such as bermudagrass (Cynodon dactylon), which is the most widely grown perennial grass in the south (Newman, 2007). Recent research identified $5 \mathrm{EFE}$ that improved the NDF digestibility (NDFD) of bermudagrass haylage and optimized their dose rates (Romero et al., 2015a,b). Whether adding $\mathrm{COF}$ to these EFE would synergistically increase their hydrolytic effects is unknown.

The current study is the third of a series of 4 studies aimed at strategic development of EFE that would increase the performance of dairy cows fed tropical forage diets. The first study tested effects of $12 \mathrm{EFE}$ on the preingestive hydrolysis, NDFD, and fermentation of bermudagrass haylage, identified the 5 most-promising EFE, and characterized proteomic differences between the most- and least-effective EFE (Romero et al., 2015a). The second study determined the optimal dose rates of the $5 \mathrm{EFE}$ (Romero et al., 2015b). The final study examined effects of adding the best EFE and dose combination identified in previous studies on the performance of dairy cows (Romero et al., 2014). The objectives of the present study were to examine if adding COF to EFE would increase the beneficial effects of the EFE on the preingestive hydrolysis and in vitro digestibility and fermentation of bermudagrass haylage. The hypothesis was that adding key COF to the EFE would increase their preingestive hydrolytic effects. Furthermore, adding key COF at an appropriate dose would synergistically increase the NDFD and fermentation of EFE-treated bermudagrass haylage.

\section{MATERIALS AND METHODS}

\section{Bermudagrass Substrate}

An established stand of bermudagrass cultivar Tifton 85 in Alachua County, Florida, was harvested, ensiled, dried, ground, and chemically characterized as described by Romero et al. (2015b). The bermudagrass haylage also contained 0.36 and $0.27 \%$ water-soluble calcium and magnesium, and 24.1, 64.3, and $0.17 \mathrm{mg} / \mathrm{L}$ of water-soluble iron, manganese, and cobalt, respectively, as determined by inductively coupled plasma spectrometry (Beliciu et al., 2012) after microwave digestion (CEM Corp., Matthews, NC) at the Dairy One Forage Laboratory, Ithaca, New York.

\section{EFE}

Five previously selected (Romero et al., 2015a) commercial and experimental EFE that were evaluated by Romero et al. (2015b) were used. Their enzymatic activities, protein concentrations, densities, forms, mineral concentrations, application rates, and biological sources are listed in Table 1. The EFE application rates were chosen because they had optimized the NDFD of bermudagrass haylage in a previous study (Romero et al., 2015b). The mineral concentrations of the EFE were determined using the methods of Beliciu et al. (2012).

\section{Screening COF for Synergistic Effects on the Hydrolytic Potential of EFE (Experiment 1)}

An experiment was carried out to determine the effects that each of $5 \mathrm{COF}$ had on EFE hydrolysis of bermudagrass haylage cell walls before consumption by animals. The quantity of water-soluble carbohydrates (WSC) released during preingestive hydrolysis of bermudagrass haylage was the primary measure of the hydrolytic potential of the EFE and COF. The preingestive hydrolysis procedure described by Krueger and Adesogan (2008) was used except that the EFE were diluted in nanopure water $(2 \mathrm{~mL})$ instead of citrate-phosphate buffer to avoid the potential chelating effects of citrate. Metal ion cofactors used were chloride salts of divalent cations of manganese, cobalt, iron, calcium, and magnesium. These COF were chosen because they had increased the activity of fibrolytic enzymes on pure substrates (BRENDA, 2013). Units for COF application rates are given in millimolar based on the convention in enzymology (BRENDA, 2013). Each COF was added to the EFE solution to achieve a final concentration of $1 \mathrm{~m} M$ (Lai et al., 2009) and sodium azide was added $(0.02 \% \mathrm{wt} / \mathrm{vol})$ to prevent substrate degradation by microbes (Krueger and Adesogan, 2008). The EFE-COF solution was added to $50-\mathrm{mL}$ tubes containing $0.5 \mathrm{~g}$ of bermudagrass haylage and the tubes were incubated for $24 \mathrm{~h}$ at $25^{\circ} \mathrm{C}$ in quadruplicate. For each EFE, 2 blank tubes without substrate were included to correct for contributions from the EFE. After the incubation, $15 \mathrm{~mL}$ of nanopure water was added and the suspension was shaken (Eberbach reciprocating shaker, model 6000, Eberbach Corporation, Ann Arbor, MI) for $1 \mathrm{~h}$ at 260 oscillations/min to extract water-soluble compounds, filtered through previously dried $\left(60^{\circ} \mathrm{C}\right.$ for $\left.48 \mathrm{~h}\right)$ and weighed $125-\mathrm{mm}$ Whatman 
Table 1. Enzymatic activities measured at 20 and $39^{\circ} \mathrm{C}$, protein concentration, form, density, application rate, mineral concentration, and biological source of exogenous fibrolytic enzyme (EFE) preparations used (adapted from Romero et al., 2014b)

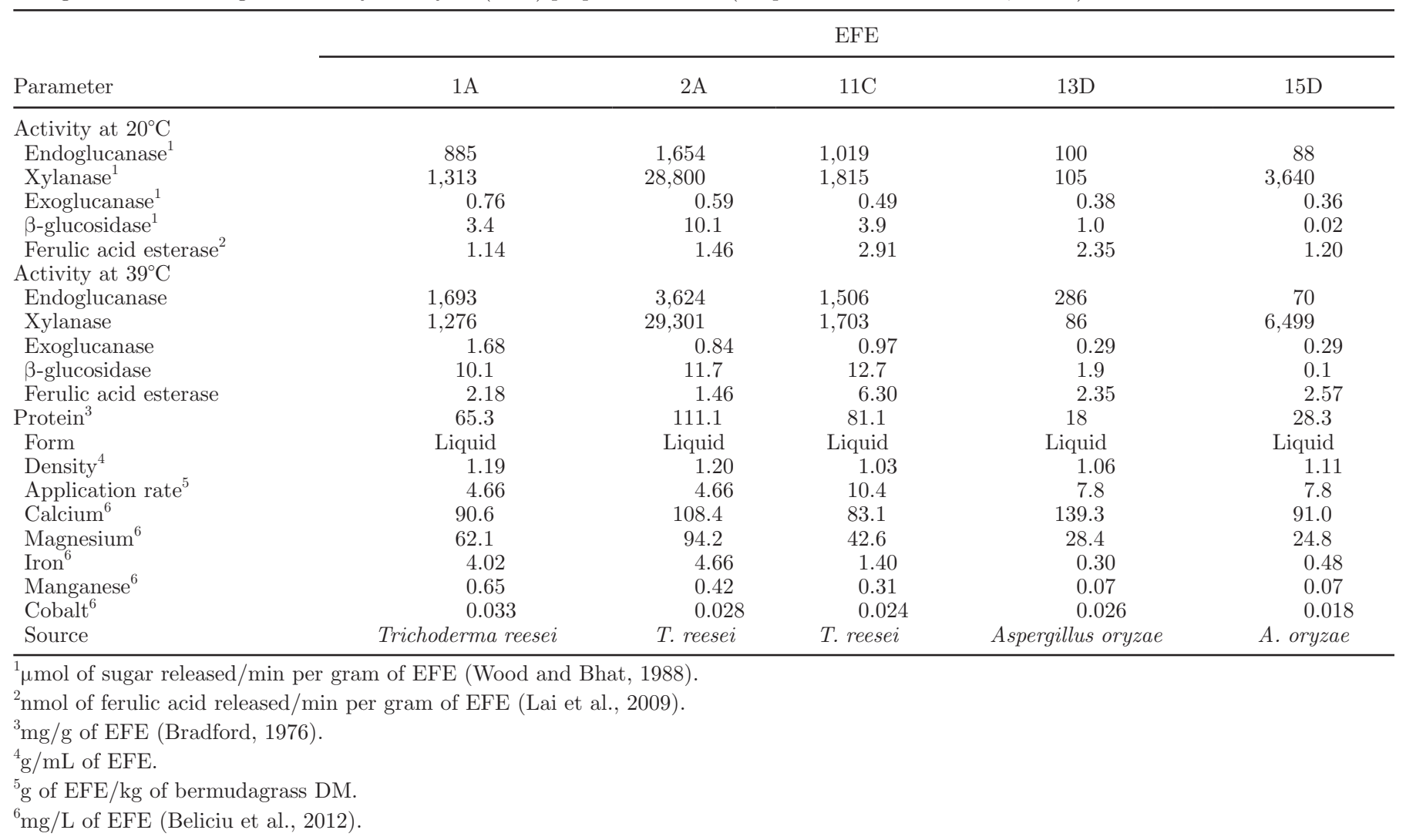

451 filter paper (Fisher Scientific, Pittsburgh, PA), and filtrate samples were frozen $\left(-20^{\circ} \mathrm{C}\right)$. Residues were dried at $60^{\circ} \mathrm{C}$ for $48 \mathrm{~h}$ in a forced-draft oven, weighed, and analyzed sequentially for NDF (Van Soest et al., 1991) and ADF (AOAC International, 2000) using an Ankom 200 Fiber Analyzer (Ankom, Macedon, NY), as described by Krueger and Adesogan (2008). Amylase was used for NDF determination but no sodium sulfite was added. The NDF and ADF results were expressed inclusive of residual ash. Hemicellulose was estimated as the difference between NDF and ADF. Residue and sample weights and DM concentrations were used to calculate DM losses. Filtrate samples were thawed and analyzed for WSC (DuBois et al., 1956) and ferulic (FER) and $p$-coumaric acids (Bio-Rad, 2011) using a Merck Hitachi Elite LaChrome HPLC system (Hitachi, L2400, Tokyo, Japan) and a Bio-Rad Aminex HPX87H column (Bio-Rad Laboratories, Hercules, CA).

\section{Effects of Adding Increasing Doses of COF to EFE on In Vitro Digestibility (Experiment 2)}

The most promising EFE-COF combinations selected in experiment $1\left(\mathrm{Mn}^{2+}+\mathrm{EFE} 11 \mathrm{C}\right.$ and $\mathrm{FE}^{2+}+$
EFE 2A or $13 \mathrm{D}$ ) were evaluated with a 24 -h in vitro ruminal digestibility assay. The COF were added to the EFE solution at doses of $0,0.1,1$, and $10 \mathrm{~m} M$ in quadruplicate. The experimental procedure was similar to that for experiment 1 except that after the $24 \mathrm{~h}$ of incubation at $25^{\circ} \mathrm{C}$, buffered-ruminal fluid $(52 \mathrm{~mL})$ was added and the suspension was incubated for $24 \mathrm{~h}$ at $39^{\circ} \mathrm{C}$ (Goering and Van Soest, 1970). The fermentation was stopped by placing the tubes on ice and contents of tubes were filtered through preweighed $125-\mathrm{mm}$ Whatman 451 paper (Fisher Scientific). Filtrate samples were immediately analyzed for $\mathrm{pH}$ using an Accumet XL25 pH meter with an automatic temperature correction feature (Fisher Scientific), acidified with 50\% $\mathrm{H}_{2} \mathrm{SO}_{4}(1 \% \mathrm{vol} / \mathrm{vol}$ of rumen fluid sample), centrifuged at $8,000 \times g$ for 20 min at $4^{\circ} \mathrm{C}$ and the supernatant was frozen $\left(-20^{\circ} \mathrm{C}\right)$. Residues were dried at $60^{\circ} \mathrm{C}$ for $48 \mathrm{~h}$, weighed, and stored at room temperature for subsequent analysis. No sodium azide was used in the EFE solution and the control treatment consisted of only nanopure water. For each EFE treatment, 2 blank tubes without substrate were included to correct for the fermentation residues resulting directly from the inoculum. The ruminal fluid was representatively collected $3 \mathrm{~h}$ after 
feeding at $0800 \mathrm{~h}$ by aspiration from 2 nonlactating, nonpregnant, ruminally cannulated Holstein cows fed coastal bermudagrass hay ad libitum supplemented with corn $(0.5 \mathrm{~kg})$, cottonseed hulls $(0.5 \mathrm{~kg})$, soybean meal $(1 \mathrm{~kg})$, and a vitamin-mineral mix $(37.5 \mathrm{~g})$. The ruminal fluid collection protocol was approved by the University of Florida, Institute of Food and Agricultural Sciences Animal Research Committee. Ruminal fluid was filtered through 4 layers of cheesecloth and flushed with $\mathrm{CO}_{2}$ before use. All tubes and the artificial saliva were prewarmed at $39^{\circ} \mathrm{C}$ and artificial saliva was flushed with $\mathrm{CO}_{2}$ before ruminal fluid addition. The concentrations of iron and manganese in the mixed rumen fluid inoculum from the 2 donor cows were 0.59 and $0.01 \mathrm{mg} / \mathrm{L}$, respectively. These were measured as described by Beliciu et al. (2012). Concentrations of minerals in rumen fluid including contributions from COF are expressed as milligrams per liter based on the convention in animal science studies. Dried residues were analyzed for NDF and ADF, and hemicellulose was calculated as previously described. Residue and original sample weights and their DM and fiber concentrations were used to calculate true DM, NDF, hemicellulose, and ADF digestibility (DMD, NDFD, HEMD, and ADFD, respectively; Mertens, 2007). Filtrate samples were analyzed for concentrations of VFA (Muck and Dickerson, 1988) with the HPLC system described previously. Ammonia-N was determined with a Technicon Auto Analyzer (Technicon, Tarrytown, NY) and an adaptation of the Noel and Hambleton (1976) procedure that involved colorimetric $\mathrm{N}$ quantification.

\section{Statistical Analyses}

Experiment 1 was analyzed as a completely randomized design with a $6(\mathrm{COF}) \times 6(\mathrm{EFE})$ factorial treatment arrangement and 4 replicates per treatment. The model used to analyze the preingestive hydrolysis data was:

$$
\mathrm{Y}_{\mathrm{ijk}}=\mu+\mathrm{T}_{\mathrm{i}}+\mathrm{C}_{\mathrm{j}}+\mathrm{TC}_{\mathrm{ij}}+\mathrm{E}_{\mathrm{ijk}},
$$

where $\mu=$ general mean; $\mathrm{T}_{\mathrm{i}}=$ effect of EFE $\mathrm{i} ; \mathrm{C}_{\mathrm{j}}=$ effect of $\mathrm{COF} j ; \mathrm{TC}_{\mathrm{ij}}=$ effect of the EFE $\mathrm{i} \times \mathrm{COF} \mathrm{j}$ interaction; and $\mathrm{E}_{\mathrm{ijk}}=$ experimental error.

The GLM procedure of SAS v.9.1 (SAS Institute, 2003) was used to analyze the data. The objective was to examine effects of $\mathrm{COF}$ on specific EFE rather than whether COF addition would make certain EFE better than others. Therefore, Fisher's F-protected least significance difference test was only used to compare COF means within each EFE. Experiment 2 was analyzed as a randomized complete block design with a $2(\mathrm{EFE}) \times$ 4 (COF dose) factorial treatment arrangement and 2 runs each with 4 replicates/treatment. The model used to analyze digestibility and fermentation data was:

$$
\begin{gathered}
\mathrm{Y}_{\mathrm{ijk}}=\mu+\mathrm{T}_{\mathrm{i}}+\mathrm{D}_{\mathrm{j}}+\mathrm{TD}_{\mathrm{ij}}+\mathrm{TR}_{\mathrm{ik}}+\mathrm{DR}_{\mathrm{ik}} \\
+\mathrm{TDR}_{\mathrm{ijk}}+\mathrm{E}_{\mathrm{ijk}},
\end{gathered}
$$

where $\mu=$ general mean; $T_{i}=$ effect of EFE $i ; D_{j}=$ effect of COF dose $\mathrm{j} ; \mathrm{R}_{\mathrm{k}}=$ effect of run $\mathrm{k}$; $\mathrm{TD}_{\mathrm{ij}}=$ effect of the EFE $\mathrm{i} \times$ COF dose $\mathrm{j}$ interaction; $\mathrm{TR}_{\mathrm{ik}}=$ effect of the EFE $\mathrm{i} \times$ run $\mathrm{k}$ interaction; $\mathrm{DR}_{\mathrm{ik}}=$ effect of the COF dose $\mathrm{j} \times$ run $\mathrm{k}$ interaction; $\mathrm{TDR}_{\mathrm{ijk}}=$ effect of the $\mathrm{EFE} \mathrm{i} \times \mathrm{COF}$ dose $\mathrm{j} \times$ run $\mathrm{k}$ interaction; and $\mathrm{E}_{\mathrm{ijk}}=$ experimental error.

Data from each EFE were analyzed separately with the GLM procedure of SAS. The model included COF dose, EFE, and their interaction. Polynomial contrasts were used to determine dose effects and the Fisher's least significance difference test was used to compare least squares means across doses. The coefficients used in these contrast statements for the unequally spaced COF doses were generated with the IML procedure of SAS. Data were tested for normality using the ShapiroWilk test, which revealed that the data were normally distributed. Significance was declared at $P \leq 0.05$.

\section{RESULTS AND DISCUSSION}

\section{Experiment 1: Effects of COF Addition on Preingestive Hydrolysis}

Applying each COF alone had no effect $(P>0.05)$ on release of WSC (Table 2). However, release of WSC was increased $(P<0.05)$ by applying EFE $1 \mathrm{~A}, 2 \mathrm{~A}, 11 \mathrm{C}$, or $15 \mathrm{D}$ alone by $96.3,238,83.7$, and $35.3 \%$, respectively, but not by applying $13 \mathrm{D}$ alone. Effects of COF addition to EFE on release of WSC depended on the EFE-COF combination $(P<0.001)$. Release of WSC was increased $(P<0.05)$ by adding $\mathrm{Fe}^{2+}$ to $1 \mathrm{~A}$ (by $4.83 \%$ ), by adding $\mathrm{Mg}^{2+}, \mathrm{Ca}^{2+}, \mathrm{Fe}^{2+}, \mathrm{Co}^{2+}$, or $\mathrm{Mn}^{2+}$ to $2 \mathrm{~A}$ (by $3.27,2.64,9.64,5.75$, and $5.29 \%$, respectively), by adding $\mathrm{Mg}^{2+}, \mathrm{Ca}^{2+}, \mathrm{Fe}^{2+}, \mathrm{Co}^{2+}$, or $\mathrm{Mn}^{2+}$ to $11 \mathrm{C}$ (by $13.18,14.61,23.50,23.21$, and $38.4 \%$, respectively), by adding $\mathrm{Fe}^{2+}, \mathrm{Co}^{2+}$, or $\mathrm{Mn}^{2+}$ to $13 \mathrm{D}$ (by 21.88, 14.06, and $13.02 \%$, respectively), and by adding $\mathrm{Fe}^{2+}$ or $\mathrm{Co}^{2+}$ to $15 \mathrm{D}$ (13.62 and $7.39 \%$, respectively).

Increases in release of WSC due to adding $\mathrm{COF}$ to $\mathrm{EFE}$ are likely to be the result of the stimulation of metal-activated enzymes rather than metalloenzymes, as almost all fiber-degrading glycoside hydrolyses catalyze acid-base reactions, which do not require the presence of a COF for catalytic activity (Harris et al., 2010). The only cellulolytic enzyme known to require a COF for hydrolysis (metalloenzyme) is polysaccharide monooxygenase, which requires copper and catalyzes 
Table 2. Effects of adding metal ion cofactors (COF), to exogenous fibrolytic enzymes (EFE) on preingestive hydrolysis of a 4-wk regrowth of bermudagrass haylage (experiment 1)

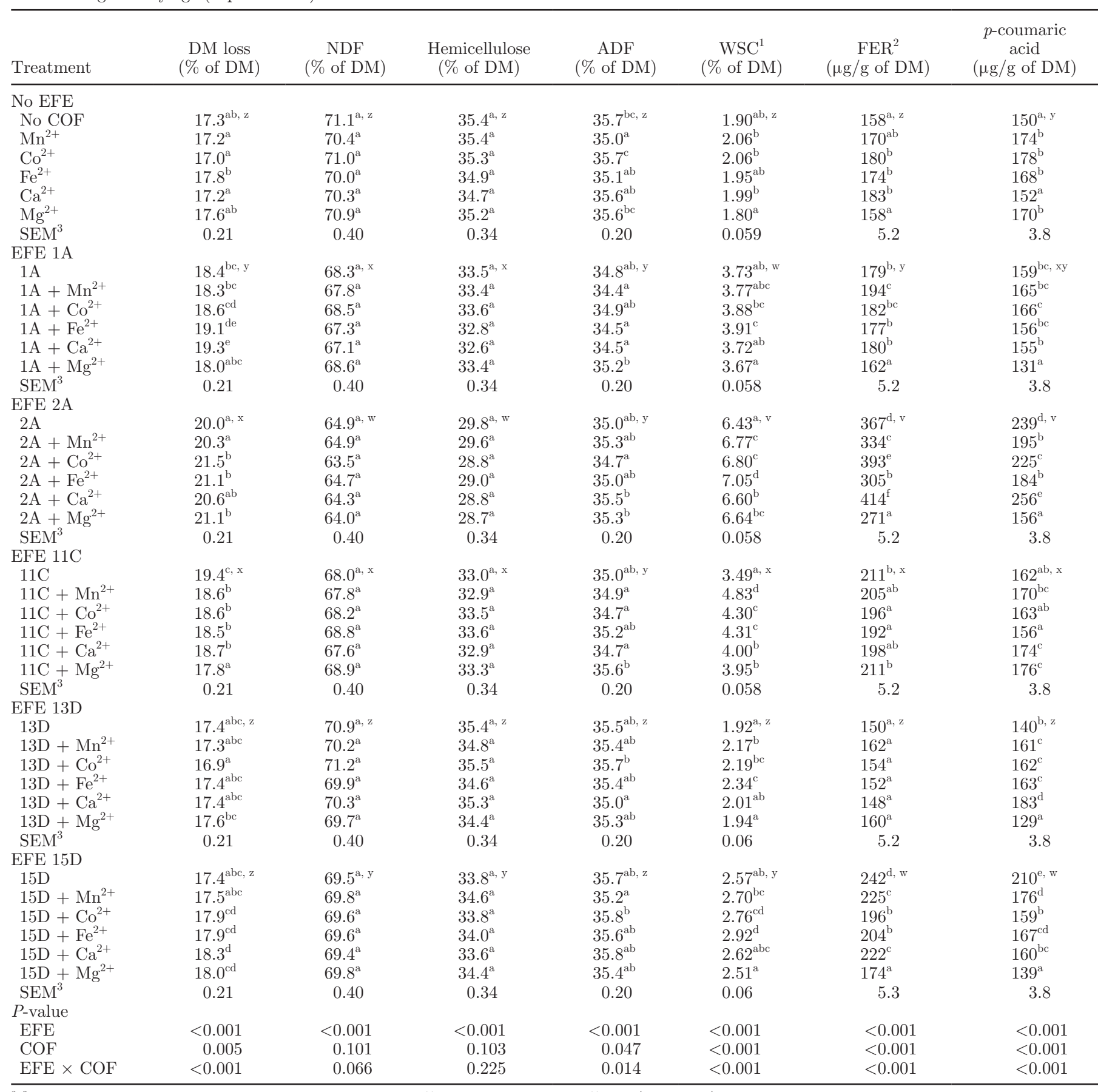

${ }^{\mathrm{a}-\mathrm{e}}$ Within EFE treatments, means in a column with different superscripts differed $(P<0.05)$.

${ }^{\mathrm{w}-\mathrm{z}}$ For EFE to which no COF were added, means in a column with different superscripts differed $(P<0.05)$.

${ }^{1} \mathrm{WSC}=$ water-soluble carbohydrates.

${ }^{2} \mathrm{FER}=$ ferulic acid.

${ }^{3}$ The SEM value is the highest among those for the specific EFE treatment in the column.

oxidation-reduction reactions (Quinlan et al., 2011). This enzyme was identified as one of the main activities in EFE 2A and 11C using isobaric tags for relative quantification-based quantitative proteomics combined with mass spectrometry (Romero et al., 2015a). To our knowledge, this is the first report of the effects of 
COF addition to EFE on release of WSC of forage cell walls, though others have investigated effects of $\mathrm{COF}$ addition to fibrolytic enzymes on hydrolysis of pure substrates (Tejirian and $\mathrm{Xu}, 2010$ ) or steam-pretreated biofuel biomass (Bin and Hongzhang, 2010).

Singh et al. (1990) reported that activity of exoglucanase II (E.C. 3.2.1.91, which acts on the nonreducing end of cellulose) from Aspergillus niger was increased 1.82-, 1.51-, 1.40-, and 1.85-fold when undisclosed doses of $\mathrm{Mn}^{2+}, \mathrm{Ca}^{2+}, \mathrm{Mg}^{2+}$, or $\mathrm{Co}^{2+}$ were added, respectively. Exoglucanases account for up to $80 \%$ of the secretome of Trichoderma reesei under cellulose-inducing conditions (Glass et al., 2013), and this activity is critical for maximum saccharification. Furthermore, T. reesei endoglucanase activity (E.C. 3.2.1.4) on carboxymethyl cellulose was increased by adding undisclosed doses of $\mathrm{Mn}^{2+}, \mathrm{Fe}^{2+}$, and $\mathrm{Co}^{2+}$, but inhibited by $\mathrm{Ca}^{2+}$ and $\mathrm{Mg}^{2+}$ (Saad and Fawzi, 2004). Also, adding $5 \mathrm{mM}$ $\mathrm{Mn}^{2+}$ to $\beta$-glucosidase (E.C. 3.2.1.21) from A. oryzae resulted in a 1.8-fold increase in activity but adding $5 \mathrm{mM} \mathrm{Fe}{ }^{3+}$ resulted in a 7.7-fold decrease in activity (Riou et al., 1998). Metal ion cofactor addition also has increased or inhibited the activity of hemicellulolytic enzymes. For instance, John and Schmidt (1988) reported that the activity of $\beta$-xylosidase (EC 3.2.1.37) from Trichoderma viride was increased by adding 1 $\mathrm{m} M \mathrm{Fe}^{2+}$ or $\mathrm{Mn}^{2+}$, but inhibited by adding $0.1 \mathrm{~m} M$ $\mathrm{Ca}^{2+}$. The EFE tested in the present study contained various fibrolytic activities; hence, it is challenging to identify which specific activities benefited from COF addition. Nevertheless, it is noteworthy that $\mathrm{Fe}^{2+}$ addition consistently improved release of WSC by all the EFE. This may be because $\mathrm{Fe}^{2+}$ increased the activities of $\beta$-xylosidase and endoglucanase, as both of these were likely present in the EFE and both have been increased by $\mathrm{Fe}^{2+}$ addition in previous research (John and Schmidt, 1988; Saad and Fawzi, 2004). The greatest increase in release of WSC occurred when $\mathrm{Fe}^{2+}$ was added to $11 \mathrm{C}$, perhaps because $11 \mathrm{C}$ had one of the lowest iron-to-protein ratios $(0.017$ vs. $0.030 \mathrm{mg}$ of iron/g of protein) and the lowest iron-to-endoglucanase ratio relative to the other EFE (0.0009 vs. $0.003 \mathrm{mg}$ of iron $/ \mathrm{mmol}$ of sugar released per minute). Adding $\mathrm{Co}^{2+}$ also increased release of WSC by all EFE except 1A. This agrees with previous work that indicated adding $\mathrm{Co}^{2+}$ increased exoglucanase (Singh et al., 1990) and endoglucanase activities (Saad and Fawzi, 2004), which determine the rate of cellulose digestion (Zhang and Lynd, 2004). The synergistic increase in release of WSC due to adding $\mathrm{Co}^{2+}$ to EFE was greatest for $11 \mathrm{C}$, probably because it had one of the lowest cobalt-to-protein ratios (0.0003 vs. $0.0006 \mathrm{mg}$ of cobalt/g of protein). Adding $\mathrm{Mn}^{2+}$ to $2 \mathrm{~A}, 11 \mathrm{~A}$, and $13 \mathrm{D}$ resulted in $1.05-$, 1.38-, and 1.13-fold increases in release of WSC. This agrees with studies showing that adding $\mathrm{Mn}^{2+}$ increased the activity of exoglucanases (Singh et al., 1990), endoglucanases (Saad and Fawzi, 2004), $\beta$-glucosidase (Riou et al., 1998), and $\beta$-xylosidase (John and Schmidt, 1988). That $\mathrm{Mn}^{2+}$ increased the activity of several fibrolytic enzymes explains why its greatest effects were on $11 \mathrm{C}$ and $2 \mathrm{~A}$, which had among the greatest total cellulolytic activities and lowest manganese-to-protein ratios (0.004 and 0.003 vs. $0.005 \mathrm{mg}$ of manganese/g of protein), respectively. Adding $\mathrm{Mg}^{2+}$ or $\mathrm{Ca}^{2+}$ only improved release of WSC by $2 \mathrm{~A}$ and $11 \mathrm{C}$, reflecting their low ratios of magnesium ( 0.71 and 0.51 vs. 1.03 $\mathrm{mg}$ of magnesium/g of protein, respectively) or calcium (0.82 and 1.00 vs. $3.80 \mathrm{mg}$ of calcium/g of protein) to protein relative to the other EFE. Also, because they are macrominerals, the concentrations of these COF in the EFE were at least 10 times greater than those of the other $\mathrm{COF}$, which are microminerals.

Compared with the respective controls, applying each COF alone had no effect $(P>0.05)$ on DM loss or hydrolysis of NDF, ADF, or hemicellulose. The only exception was that applying $\mathrm{Mn}^{2+}$ reduced $(P<0.05)$ the ADF concentration by $1.96 \%$ but the corresponding increase in WSC concentration was not statistically significant $(P>0.05)$.

Applying EFE 1A, 2A, 11C, or 15D alone increased $(P<0.05)$ NDF hydrolysis by $3.94,8.72,4.36$, and $2.25 \%$, respectively, whereas applying $13 \mathrm{D}$ alone did not. Effects of EFE addition on NDF hydrolysis tended $(P=0.066)$ to be influenced by COF addition. Theoretically, most WSC released during cell wall saccharification by EFE should have been generated by NDF hydrolysis, thus NDF values were expected to decrease as WSC concentrations increased due to saccharification. However, NDF analysis is less precise than many other chemical components of forages, such as WSC, as evidenced by the greater coefficient of variation recommended for NDF assays versus those of other forage chemical components (Galyean, 2010). The variability in the NDF concentrations in our study ( $\mathrm{SEM}=0.46 \%$ units of bermudagrass haylage DM) was identical to the average increase in WSC due to COF addition, thus preventing detection of differences in NDF due to saccharification. In theory, using the Uppsala dietary fiber scheme (Theander, 1995) instead of the NDF scheme to evaluate EFE effects on cell wall saccharification may be more appropriate because it quantifies individual cell wall polysaccharides rather than detergent soluble or insoluble fiber fractions. However, the Uppsala dietary fiber results are less precise than those from the NDF scheme (SD of 3.2 vs. $1.3 \%$, respectively; Mertens, 2003).

Applying EFE 1A, 2A, 11C, or 15D alone reduced $(P$ $<0.05)$ hemicellulose concentration by $5.37,15.82,6.78$, 
and $4.52 \%$, respectively, whereas applying 13D alone did not. Effects of EFE addition on hemicellulose were not influenced by COF addition $(P=0.225)$. In our previous studies, hemicellulose was the fraction mostly hydrolyzed by EFE (Romero et al., 2015a,b). The structure of xylan is more complex than that of cellulose due to its substitutions, which necessitate a greater variety of enzymes with different specificities for its degradation. However, xylan does not form tightly packed crystalline structures as cellulose does and is, thus, more accessible to enzymatic hydrolysis (Saha, 2003).

Applying EFE 1A, 2A, or $11 \mathrm{C}$ alone reduced $(P<$ $0.05)$ ADF concentration by $2.52,1.96$, and $1.96 \%$, respectively, whereas applying $13 \mathrm{D}$ and $15 \mathrm{D}$ alone did not. Effects of COF addition to EFE on ADF hydrolysis depended on the EFE-COF combination $(P<0.05)$, yet adding $\mathrm{COF}$ did not affect $\mathrm{ADF}$ hydrolysis by any EFE.

Applying EFE 1A, 2A, or 11C alone increased $(P<$ $0.05) \mathrm{DM}$ loss by $6.36,15.6$, and $12.14 \%$, respectively, whereas applying 13D or 15D alone did not. Effects of $\mathrm{COF}$ addition to $\mathrm{EFE}$ on DM loss depended on the EFE-COF combination $(P<0.001)$. Dry matter loss was increased $(P<0.05)$ by adding $\mathrm{Ca}^{2+}$ and $\mathrm{Fe}^{2+}$ to $1 \mathrm{~A}$ (4.89 and $3.80 \%$, respectively); $\mathrm{Mg}^{2+}, \mathrm{Fe}^{2+}$, and $\mathrm{Co}^{2+}$ to $2 \mathrm{~A}\left(5.50,5.50\right.$, and $7.50 \%$, respectively); $\mathrm{Mg}^{2+}, \mathrm{Ca}^{2+}$, $\mathrm{Fe}^{2+}, \mathrm{Co}^{2+}$, and $\mathrm{Mn}^{2+}$ to $11 \mathrm{C}(8.25,3.61,4.64,4.12$, and $4.12 \%$, respectively). No changes were observed when COF were added to EFE 13D and 15D.

Surprisingly, adding $\mathrm{Ca}^{2+}, \mathrm{Fe}^{2+}$, or $\mathrm{Co}^{2+}$ alone increased the concentration of FER $(P<0.05)$, though adding $\mathrm{Mg}^{2+}$ or $\mathrm{Mn}^{2+}$ had no effect $(P>0.05)$. The mechanism by which certain COF increased the FER concentration in the absence of EFE is unknown. Hydration during COF addition may be implicated and the COF may have stimulated endogenous FER esterases in bermudagrass haylage or dead silage bacteria, resulting in the increased FER concentrations. Neither microbial growth nor cross reaction with a reagent can be implicated due to the addition of sodium azide during the incubation and the use of HPLC to quantify FER, respectively. In support of the latter suggestion, Sang et al. (2011) reported that $5 \mathrm{mM} \mathrm{Ca}{ }^{2+}, \mathrm{Fe}^{3+}$, and $\mathrm{Co}^{2+}$ stimulated ferulic acid esterase activity from an unculturable soil bacterium. Adding EFE 1A, 2A, 11C, or $15 \mathrm{D}$ alone increased the concentration of FER $(P$ $<0.05)$, but $13 \mathrm{D}$ did not. Effects of $\mathrm{COF}$ addition to EFE on release of FER depended on the EFE-COF combination $(P<0.001)$. For instance, adding $\mathrm{Mn}^{2+}$ to $1 \mathrm{~A}$ increased the response but adding $\mathrm{Mg}^{2+}$ decreased it. Furthermore, adding $\mathrm{Ca}^{2+}$ or $\mathrm{Co}^{2+}$ to $2 \mathrm{~A}$ increased the responses but adding $\mathrm{Mg}^{2+}, \mathrm{Fe}^{2+}$ or $\mathrm{Mn}^{2+}$ decreased them $(P<0.05)$. In addition, adding $\mathrm{Fe}^{2+}$ and $\mathrm{Co}^{2+}$ to $11 \mathrm{C}$ decreased the response, as did adding $\mathrm{Mg}^{2+}$,
$\mathrm{Ca}^{2+}, \mathrm{Fe}^{2+}, \mathrm{Co}^{2+}$, and $\mathrm{Mn}^{2+}$ to $15 \mathrm{D}$. No change in FER was detected when COF were added to 13D. Therefore, FER release was only increased by adding $\mathrm{Mn}^{2+}$ to $1 \mathrm{~A}$ or by adding $\mathrm{Ca}^{2+}$ or $\mathrm{Co}^{2+}$ to $2 \mathrm{~A}$. No published studies that examined effects of adding $\mathrm{Mn}^{2+}$ to T. reesei ferulic acid esterase were found, but Kanauchi et al. (2008) reported that $\mathrm{Mn}^{2+}$ inhibited ferulic acid esterase from A. awamori. The increase in FER due to adding $\mathrm{Ca}^{2+}$ to $2 \mathrm{~A}$ was 1.8 times greater than that detected by adding $\mathrm{Ca}^{2+}$ alone, whereas that due to adding $\mathrm{Co}^{2+}$ was only 1.2 times greater than that due to adding $\mathrm{Co}^{2+}$ alone. Thus, $\mathrm{Ca}^{2+}$ was more effective at synergistically increasing the release of FER.

Adding $\mathrm{Mg}^{2+}, \mathrm{Fe}^{2+}, \mathrm{Co}^{2+}$, or $\mathrm{Mn}^{2+}$ alone increased the $p$-coumaric concentration $(P<0.05)$, as did adding $2 \mathrm{~A}, 11 \mathrm{C}$, or $15 \mathrm{D}$ alone $(P<0.05)$. However, effects of COF addition to EFE on release of $p$-coumaric depended on the EFE-COF combination $(P<0.001)$. The concentration of $p$-coumaric was decreased $(P<0.05)$ by adding $\mathrm{Mg}^{2+}$ to $1 \mathrm{~A}, \mathrm{Mg}^{2+}, \mathrm{Fe}^{2+}, \mathrm{Co}^{2+}$, or $\mathrm{Mn}^{2+}$ to $2 \mathrm{~A}, \mathrm{Mg}^{2+}$ to $13 \mathrm{D}$, or $\mathrm{Mg}^{2+}, \mathrm{Ca}^{2+}, \mathrm{Fe}^{2+}, \mathrm{Co}^{2+}$, and $\mathrm{Mn}^{2+}$ to $15 \mathrm{D}$. In contrast, $p$-coumaric concentration was increased $(P<0.05)$ by adding $\mathrm{Ca}^{2+}$ to $2 \mathrm{~A}, \mathrm{Mg}^{2+}$ or $\mathrm{Ca}^{2+}$ to $11 \mathrm{C}$, or $\mathrm{Ca}^{2+}, \mathrm{Fe}^{2+}, \mathrm{Co}^{2+}$, or $\mathrm{Mn}^{2+}$ to $13 \mathrm{D}$. Hence, when added to EFE, $\mathrm{Ca}^{2+}$ synergistically increased release of $p$-coumaric from the cell wall more consistently than other COF. Yet, McCrae et al. (1994) reported no changes in Aspergillus awamori p-coumaroyl esterase activity when $20 \mathrm{mM} \mathrm{Ca}{ }^{2+}$ was added perhaps because of their high dose and the different EFE source they used.

\section{Experiment 2: Effects of COF Addition to EFE on Digestibility and Fermentation}

Effects of adding $\mathrm{Mn}^{2+}$ to $11 \mathrm{C}$ or $\mathrm{Fe}^{2+}$ to EFE $2 \mathrm{~A}$ or $13 \mathrm{D}$ on the main digestibility and ruminal measures are shown below, and effects on additional indices of ruminal fermentation ( $\mathrm{pH}$, butyrate, isobutyrate, isovalerate, and ammonia-N) are presented in the Appendix.

Manganese Addition to EFE 11 C. Adding $\mathrm{Mn}^{2+}$ to $11 \mathrm{C}$ gave one of the greatest increases in release of WSC in experiment 1, hence effects of this EFE$\mathrm{COF}$ combination on digestibility and fermentation were explored in experiment 2. Adding EFE 11C alone increased DMD, NDFD, HEMD, and ADFD (Table 3; $P<0.001)$. Increasing the rate of $\mathrm{Mn}^{2+}$ application with or without EFE $11 \mathrm{C}$ resulted in linear $(P<0.01)$ increases in DMD and NDFD, but the increments were greater when $11 \mathrm{C}$ was present $\left(\mathrm{EFE} \times \mathrm{Mn}^{2+}\right.$ dose interaction; $P<0.05)$. Adding $10 \mathrm{mM} \mathrm{Mn}{ }^{2+}$ to $11 \mathrm{C}$ resulted in a $3.5 \%$ increase in DMD beyond the $6.6 \%$ increase caused by adding $11 \mathrm{C}$ alone and a $7.3 \%$ increase beyond the $2.7 \%$ increase caused by adding $10 \mathrm{~m} M \mathrm{Mn}^{2+}$ alone. 
Likewise, adding $10 \mathrm{mM} \mathrm{Mn^{2+ }}$ to $11 \mathrm{C}$ resulted in a $8.1 \%$ increase in NDFD beyond the $15.5 \%$ increase caused by adding $11 \mathrm{C}$ alone and a $17.2 \%$ increase beyond the

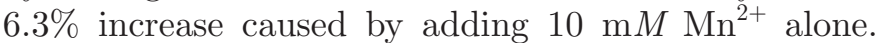
Therefore, adding $\mathrm{Mn}^{2+}$ synergistically increased the digestibility of bermudagrass haylage by EFE 11C.The increases in DMD and NDFD due to adding 0 versus 10 $\mathrm{mMMn}{ }^{2+}$ are attributable to corresponding increases in ADFD $(P<0.001)$, yet HEMD was unaffected by $\mathrm{Mn}^{2+}$ dose. These results may indicate that cellulolytic activities were stimulated by adding $\mathrm{Mn}^{2+}$ but xylanolytic activities were not. Manganese increases the activity of exoglucanases, endoglucanases, and $\beta$-glucosidases (Singh et al., 1990; Riou et al., 1998; Saad and Fawzi, 2004), which are all involved in cellulose depolymerization. In an early study by Chamberlain and Burroughs (1962), omission of manganese from an in vitro ruminal fluid medium reduced cellulose digestibility. In agreement, Arelovich et al. (2000) reported an increase in in vitro DMD of prairie hay (44.7 vs. $42.0 \%$ of DM) due to adding up to $100 \mathrm{mg} / \mathrm{L}$ of $\mathrm{Mn}^{2+}$ (chloride salt) to ruminal fluid. Martinez and Church (1970) also reported that adding over $100 \mathrm{mg} / \mathrm{L}$ of $\mathrm{Mn}^{2+}$ (sulfate salt) reduced cellulose digestion by washed suspensions of rumen microbes, but adding 5 to $30 \mathrm{mg} / \mathrm{L}$ of $\mathrm{Mn}^{2+}$ optimized the digestion. In our study, the manganese concentrations in the buffered-ruminal incubation fluid were $3.16,3.37,5.20$, and $23.5 \mathrm{mg} / \mathrm{L}$ for $\mathrm{Mn}^{2+}$ doses of $0,0.1,1$, and $10 \mathrm{~m} M$ in the EFE $11 \mathrm{C}$ solution, respectively. Therefore, the 1 and $10 \mathrm{~m} M$ doses were within the range reported to stimulate digestion by ruminal bacteria in the previous study. This may explain why adding $10 \mathrm{mM} \mathrm{Mn}{ }^{2+}$ to $11 \mathrm{C}$ synergistically increased NDFD in the current study. The mixed rumen fluid inoculum had a manganese concentration of $0.01 \mathrm{mg} / \mathrm{L}$, which is below the optimal ranges of 1 to 10 and 0.4 to $11 \mathrm{mg} / \mathrm{L}$ suggested by Durand and Kawashima (1980) and Mackie and Therion (1984), respectively. In our study, supplemental manganese from the Goering and Van Soest (1970) medium provided $2.6 \mathrm{mg} / \mathrm{L}$ and the bermudagrass substrate provided $0.6 \mathrm{mg} / \mathrm{L}$ of in vitro medium. Therefore, the total concentration of manganese was within the optimal range required to optimize fermentation of the in vitro system. Manganese concentrations of $0.25,0.39,0.52$, and $1.03 \mathrm{mg} / \mathrm{L}$ were reported in the rumen fluid of ewes fed orchardgrass hay (Ishida et al., 1988), sheep fed dried grass (Bremner, 1970), cows fed roughage plus concentrate (Nikolic et al., 1978), and steers fed hay with or without added $\mathrm{CuSO}_{4}$ (Wetzel and Menke, 1978).

Applying $11 \mathrm{C}$ alone increased concentrations of acetate and propionate and decreased the acetate-topropionate ratio $(\mathbf{A}: \mathbf{P})$. An EFE $\times \mathrm{Mn}^{2+}$ dose interaction $(P=0.002)$ was detected for total VFA. Increasing

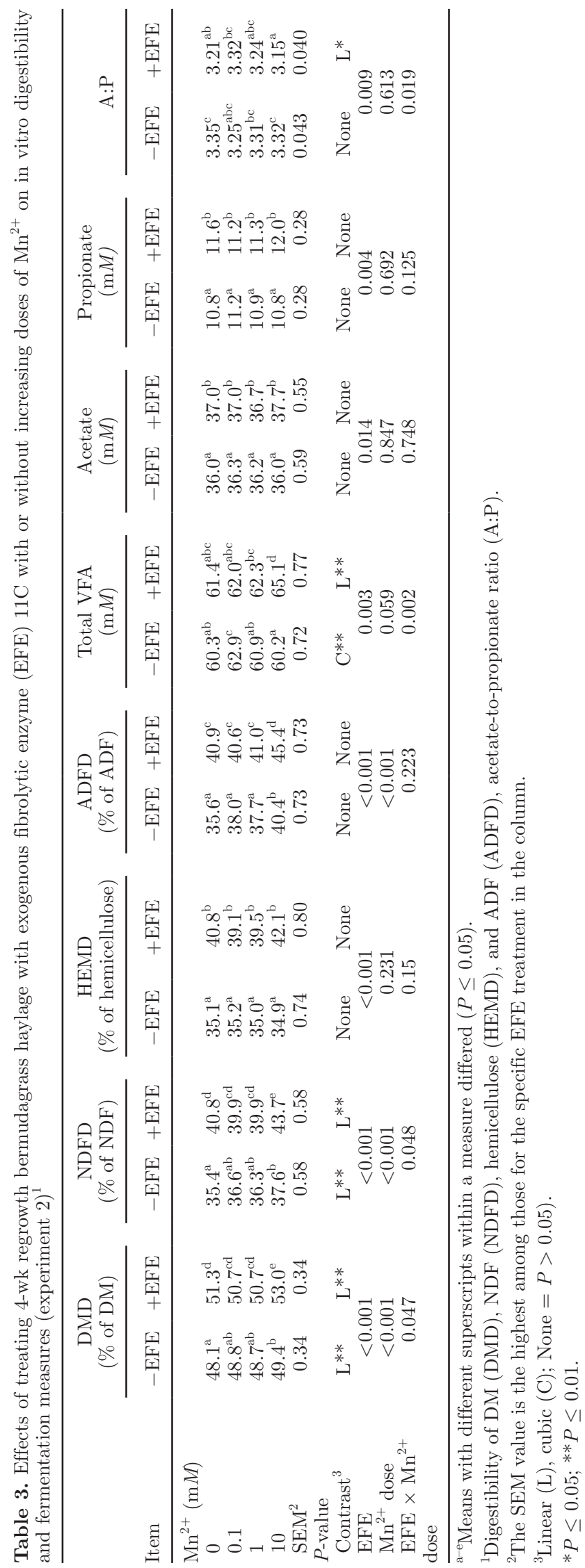


the $\mathrm{Mn}^{2+}$ dose in the absence of $11 \mathrm{C}$ resulted in a cubic total VFA response $(P<0.01)$, in which only the 0.1 $\mathrm{m} M$ dose increased total VFA concentration compared with $0 \mathrm{~m} M(4.31 \% ; P<0.05)$. The reasons behind this cubic response are unclear. However, when EFE $11 \mathrm{C}$ was present, total VFA concentration increased linearly $(P<0.01)$ with increasing $\mathrm{Mn}^{2+}$ dose. Biswas and Purnendu (2012) and Durand and Kawashima (1980) also reported that total VFA concentration was increased by adding manganese to the ruminal incubation fluid used to ferment rice straw- and prairie hay-based diets, respectively. In our study, the $10 \mathrm{mM}$ $\mathrm{Mn}^{2+}$ dose along with EFE $11 \mathrm{C}$ increased $(P<0.05)$ total VFA concentration by $6.1 \%$ relative to the value achieved by adding $11 \mathrm{C}$ alone in agreement with corresponding synergistic increases in DMD and NDFD. Therefore, adding $10 \mathrm{mM} \mathrm{M{ } ^ { 2 + }}$ to $11 \mathrm{C}$ may synergistically increase energy supply to cows.

Effects of $11 \mathrm{C}$ on the A:P ratio were influenced by adding $\mathrm{Mn}^{2+}(P<0.02)$. In the absence of $11 \mathrm{C}$, no $\mathrm{Mn}^{2+}$ dose effects on A:P ratio were evident, but in the presence of $11 \mathrm{C}$ increasing the $\mathrm{Mn}^{2+}$ dose linearly decreased the A:P ratio $(P<0.05)$. Therefore, adding $\mathrm{Mn}^{2+}$ to $11 \mathrm{C}$ would likely increase the potential beneficial effects of $11 \mathrm{C}$ on ruminal energy supply (from gluconeogenic substrates). Adding increasing doses of $\mathrm{Mn}^{2+}$ to $11 \mathrm{C}$ resulted in cubic fluctuations $(P<0.01)$ in concentrations of isovalerate and valerate $(\mathrm{EFE} \times$ $\mathrm{Mn}^{2+}$ dose interaction; $\left.P<0.05\right)$.

Iron Addition to EFE $2 A$ or 13D. Adding $\mathrm{Fe}^{2+}$ to EFE 2A or 13D resulted in some of the greatest increases in release of WSC in experiment 1; hence, effects of these EFE-COF combinations on digestibility and fermentation were explored in experiment 2. Adding EFE 2A or 13D alone increased DMD, NDFD, and ADFD and 2A also increased HEMD (Tables 4 and 5; $P<0.001)$. Increasing the rate of $\mathrm{Fe}^{2+}$ application linearly decreased $(P<0.01)$ all digestibility measures in the absence of $2 \mathrm{~A}$, but had no effect in the presence of $2 \mathrm{~A}\left(\mathrm{EFE} \times \mathrm{Fe}^{2+}\right.$ dose interaction; $\left.P<0.05\right)$. Therefore, $2 \mathrm{~A}$ retained its hydrolytic effect in the presence of $\mathrm{Fe}^{2+}$ and prevented adverse effects of adding $10 \mathrm{mM}$ $\mathrm{Fe}^{2+}$ alone on DMD (-6.03\%), NDFD $(-14.41 \%)$, and HEMD (-14.24\%), This suggests that certain EFE can be used to reduce adverse effects of $\mathrm{Fe}^{2+}$ toxicity on the digestion of feeds. Harrison et al. (1992) reported that ferric and ferrous cations consistently inhibited the DM digestion of a forage-based TMR by up to $36 \%$ when added to ruminal fluid cultures at concentrations of 100 to $1,000 \mathrm{mg} / \mathrm{L}$. The toxicity of heavy metals, such as iron in anaerobic environments is attributable to the disruption of enzymatic activity and structural binding of the metals with thiol and other groups on protein molecules or by replacing naturally occurring metals in enzyme prosthetic groups (Chen et al., 2008). More research is required to understand and exploit the beneficial effects of adding fungal enzymes to rumen fluid media with high iron concentrations.

Increasing the rate of $\mathrm{Fe}^{2+}$ application linearly decreased $(P<0.01)$ DMD, NDFD, and ADFD in the presence or absence of 13D, but only decreased HEMD in the absence of the EFE. Therefore, adding $10 \mathrm{mM}$ $\mathrm{Fe}^{2+}$ to $13 \mathrm{D}$ prevented the beneficial effects of adding $13 \mathrm{D}$ alone on DMD and NDFD $\left(\mathrm{EFE} \times \mathrm{Fe}^{2+}\right.$ dose interaction; $P<0.05$ ). Harrison et al. (1992) found that adding $100 \mathrm{mg} / \mathrm{L}$ of $\mathrm{Fe}^{2+}$ (chloride salt) to the ruminal incubation fluid reduced $(-10.18 \%)$ the DMD of a fescue-based TMR compared with adding no $\mathrm{Fe}^{2+}$. Martinez and Church (1970) reported that adding up to $50 \mathrm{mg} / \mathrm{L}$ of $\mathrm{Fe}^{3+}$ (chloride salt) had no toxic or negative effects on cellulose digestion by washed suspensions of rumen microbes, and adding 2 to $5 \mathrm{mg} / \mathrm{L}$ of $\mathrm{Fe}^{3+}$ increased the response. In our study, adding $0,0.1,1$, and $10 \mathrm{mM} \mathrm{Fe}{ }^{2+}$ to $2 \mathrm{~A}$ or $13 \mathrm{D}$ resulted in mean iron concentrations in the incubation fluid of 1.86, 2.07, 3.93 , and $22.55 \mathrm{mg} / \mathrm{L}$, respectively. Therefore, the results of the present study seem to indicate that a lower ruminal fluid iron concentration $(22.5 \mathrm{mg} / \mathrm{L})$ than that indicated by Martinez and Church (1970; $50 \mathrm{mg} / \mathrm{L}$ ) can cause iron toxicity in ruminal in vitro incubations. Different toxicity outcomes among the latter study and ours may be because washed microbe suspensions were used in the latter study instead of the whole rumen fluid used in the current experiment. However, the lower iron doses used in our study ( 0.1 to $1 \mathrm{~m} M)$ did not decrease digestibility and the doses resulted in ruminal fluid iron concentrations that were within the optimal range recommended for optimizing microbial metabolism by Durand and Kawashima (1980).

The mixed rumen fluid inoculum had a concentration of $0.59 \mathrm{mg} / \mathrm{L}$ of iron, which is similar to the value observed in steers fed orchardgrass hay $(0.5 \mathrm{mg} / \mathrm{L}$; Ishida et al., 1988), but below the optimal range of 1 to 10 mg/L suggested by Durand and Kawashima (1980) and the value observed by Nikolic et al. (1978) in cows fed undisclosed roughage plus concentrate $(8.17 \mathrm{mg} / \mathrm{L})$. In the present study, supplemental iron from the Goering and Van Soest (1970) medium provided $1.5 \mathrm{mg} / \mathrm{L}$ and the bermudagrass substrate provided $0.2 \mathrm{mg} / \mathrm{L}$ of in vitro medium. Therefore, the iron concentration in the in vitro system was within the optimal range.

No EFE $\times \mathrm{Fe}^{2+}$ dose interaction was detected $(P>$ $0.05)$ for $\mathrm{ADFD}$ due to adding $\mathrm{Fe}^{2+}$ to $2 \mathrm{~A}$ or $13 \mathrm{D}$. Yet, unlike lower doses, adding $10 \mathrm{~m} M \mathrm{Fe}^{2+}$ decreased ADFD. Therefore, it seems that EFE $2 \mathrm{~A}$ and $13 \mathrm{D}$ were more effective at preventing adverse effects of $\mathrm{Fe}^{2+}$ addition on digestion of hemicellulose than on ADF digestion. Riou et al. (1998) reported that a $\beta$-glucosidase from 

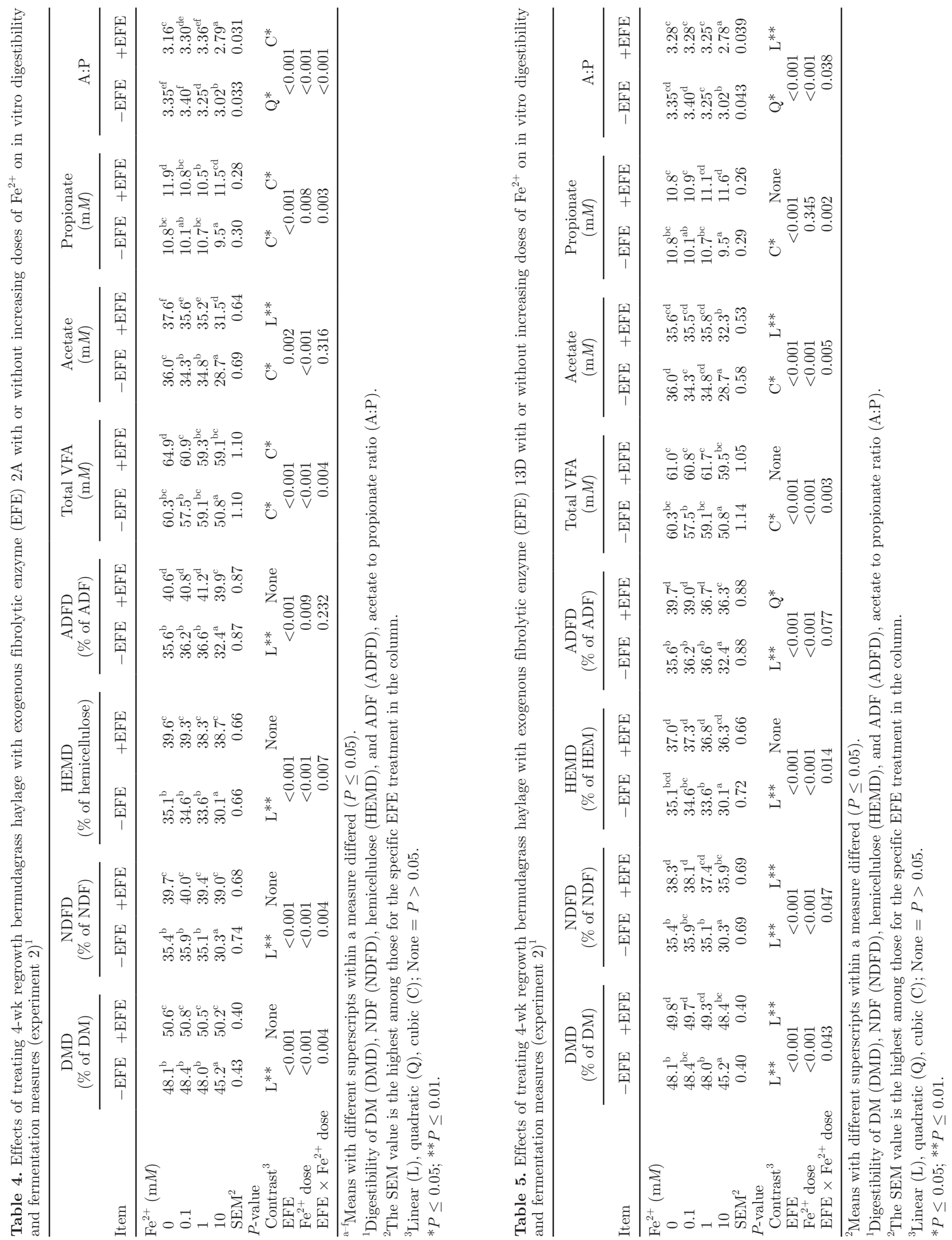
A. oryzae was inhibited strongly by $5 \mathrm{mM} \mathrm{Fe} \mathrm{F}^{3+}$, which could partly explain the inhibition of ADF digestion by high concentrations of iron in our study. In general, $13 \mathrm{D}$ was more susceptible than EFE $2 \mathrm{~A}$ to the deleterious effects on digestibility of high iron concentrations.

Adding increasing doses of $\mathrm{Fe}^{2+}$ alone decreased A:P $(P<0.05$, quadratic $)$ as well as total VFA, acetate, and propionate concentrations $(P<0.05$, cubic), whereas adding $2 \mathrm{~A}$ alone increased total VFA, acetate, and propionate concentrations and decreased the A:P ratio $(P<0.05)$. Adding as little as $0.1 \mathrm{~m} M \mathrm{Fe}^{2+}$ to $2 \mathrm{~A}$ prevented the increase in total VFA caused by treatment with $2 \mathrm{~A}$ alone, but no further decrease was detected as the $\mathrm{Fe}^{2+}$ dose increased $\left(\mathrm{EFE} \times \mathrm{Fe}^{2+}\right.$ dose interaction; $P=0.004)$. Increasing the dose of the $\mathrm{Fe}^{2+}$ added to $2 \mathrm{~A}$ resulted in cubic effects $(P<0.05)$ on propionate and A:P ratio. The reasons for the cubic responses are unclear. Harrison et al. (1992) reported that adding 100,200 , and $500 \mathrm{mg} / \mathrm{L}$ of $\mathrm{Fe}^{2+}$ increased total VFA concentration, but no further increase occurred when $1,000 \mathrm{mg} / \mathrm{L}$ were added. However, in their experiment, ferrous sulfate was used rather than the ferrous chloride used in our study. The form of the iron likely determines the outcome, as it affects its solubility. The sulfate in ferrous sulfate would be rapidly metabolized to sulfide in the rumen, forming a black precipitate, which complexes with iron and makes it less soluble and accessible to rumen microbes, whereas ferrous chloride is more soluble and consequently more toxic (Harrison et al., 1992).

Adding increasing doses of $\mathrm{Fe}^{2+}$ to $13 \mathrm{D}$ did not affect total VFA concentration $\left(\mathrm{EFE} \times \mathrm{Fe}^{2+}\right.$ dose interaction; $P<0.01$ ), but linearly decreased the acetate concentration and the A:P ratio $(P<0.05)$. Adding $10 \mathrm{~m} M \mathrm{Fe}^{2+}$ to $13 \mathrm{D}$ increased propionate concentration relative to adding $13 \mathrm{D}$ alone, but lower doses did not $\left(\mathrm{EFE} \times \mathrm{Fe}^{2+}\right.$ dose interaction; $P<0.01$ ).

In summary, adding $\mathrm{Fe}^{2+}$ to $2 \mathrm{~A}$ or $13 \mathrm{D}$ is not recommended because though they increased release of WSC, they did not influence and in fact mostly decreased beneficial effects of the EFE on measures of digestibility and fermentation in the current study. Even the slight increase in propionate concentration and the decrease in $\mathrm{A}: \mathrm{P}$ ratio due to adding $10 \mathrm{~m} M \mathrm{Fe}^{2+}$ to $13 \mathrm{D}$ are likely outweighed by corresponding decreases in DMD, NDFD, and ADFD.

\section{CONCLUSIONS}

Adding $1 \mathrm{~m} M$ each of the COF to EFE $2 \mathrm{~A}$ or $11 \mathrm{C}$ synergistically increased release of WSC of bermudagrass haylage, as did adding $1 \mathrm{~m} M \mathrm{Fe}^{2+}$ to $1 \mathrm{~A}, \mathrm{Mn}^{2+}$, $\mathrm{Co}^{2+}$, and $\mathrm{Fe}^{2+}$ to $13 \mathrm{D}$, or $\mathrm{Co}^{2+}$ or $\mathrm{Fe}^{2}$ to $15 \mathrm{D}$. The greatest release of WSC was obtained by adding $\mathrm{Mn}^{2+}$ to $11 \mathrm{C}(38 \%)$ or by adding $\mathrm{Fe}^{2+}$ to $2 \mathrm{~A}$ or $13 \mathrm{D}$ (10 and $21.9 \%$, respectively). Effects of adding increasing doses of these COF on EFE-mediated changes in vitro digestibility depended on the COF and EFE. Adding $10 \mathrm{mM}$ $\mathrm{Mn}^{2+}$ to EFE $11 \mathrm{C}$ resulted in a $8.1 \%$ increase in NDFD beyond the $15.5 \%$ increase caused by adding EFE $11 \mathrm{C}$ alone and a $17.2 \%$ increase beyond the $6.3 \%$ increase

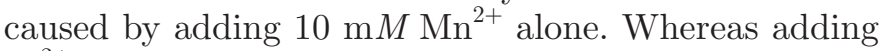
$\mathrm{Fe}^{2+}$ to $2 \mathrm{~A}$ had no effects on EFE-mediated digestibility responses but $2 \mathrm{~A}$ prevented adverse effects of adding $\mathrm{Fe}^{2+}$ alone on DMD and NDFD. In contrast, adding $\mathrm{Fe}^{2+}$ to $13 \mathrm{D}$ reduced the increases in NDFD caused by adding the EFE alone. This study shows that adding COF to EFE can synergistically increase, decrease, or not affect the hydrolytic effects of EFE on forage cell walls depending on the specific EFE-COF combination. More work is required to understand the mechanisms resulting in these outcomes to exploit beneficial effects of $\mathrm{COF}$ on EFE.

\section{ACKNOWLEDGMENTS}

We gratefully acknowledge the statistical advice of Mihai Giurcanu of the Statistical Consulting Unit at the Institute of Food and Agricultural Sciences, University of Florida, as well as funding for the project by a USDA-Tropical Subtropical Agricultural Research grant.

\section{REFERENCES}

Adesogan, A. T., Z. X. Ma, J. J. Romero, and K. G. Arriola. 2014. Improving cell wall digestion and animal performance with fibrolytic enzymes. J. Anim. Sci. 92:1317-1330.

AOAC International. 2000. Official Methods of Analysis. 17th ed. AOAC International, Arlington, VA.

Arelovich, H. M., F. N. Owens, G. W. Horn, and J. A. Vizcarra. 2000. Effects of supplemental zinc and manganese on ruminal fermentation, forage intake, and digestion by cattle fed prairie hay and urea. J. Anim. Sci. 78:2972-2979.

Arriola, K. G., J. J. Romero, and A. T. Adesogan. 2011. Effects of $\mathrm{pH}$ and temperature on fibrolytic enzyme activities of various commercial exogenous enzyme preparations. J. Anim. Sci. 89(ESuppl. 1):554. (Abstr).

Beauchemin, K. A., and L. Holtshausen. 2010. Developments in enzyme usage in ruminants. Pages 206-230 in Enzymes in Farm Animal Nutrition, 2nd ed. M. R. Bedford and G. G. Partridge, ed. CAB International, Wallingford, UK.

Beliciu, C. M., A. Sauer, and C. I. Moraru. 2012. The effect of commercial sterilization regimens on micellar casein concentrates. J. Dairy Sci. 95:5510-5526.

Bin, Y., and C. Hongzhang. 2010. Effect of the ash on enzymatic hydrolysis of steam-exploded rice straw. Bioresour. Technol. 101:9114-9119.

Bio-Rad. 2011. Overview and strategies for bio-organic molecule purification. Accessed Apr. 16, 2015. http://www.bio-rad.com/webroot/web/pdf/lsr/literature/Bulletin_1928.pdf.

Biswas, P. K., and B. Purnendu. 2012. In vitro evaluation of a diet supplemented with Mn on nutrient digestibility and rumen fermentation pattern in cattle. Explor. Anim. Med. Res. 1:161-166.

Bradford, M. 1976. A rapid and sensitive method for the quantitation of microgram quantities of protein utilizing the principle of protein-dye binding. Anal. Biochem. 72:248-254. 
Bremner, I. 1970. Zinc, copper and manganese in the alimentary tract of sheep. Br. J. Nutr. 24:769-783.

BRENDA. 2013. The Comprehensive Enzyme Information System. Accessed Nov. 10, 2013. http://www.brenda-enzymes.org/.

CAZy. 2013. Carbohydrate-Active Enzymes Database. Accessed Nov. 10, 2013. http://www.cazy.org/.

Chamberlain, C. C., and W. Burroughs. 1962. Effect of fluoride, magnesium and manganese ions on in vitro cellulose digestion by rumen microorganisms. J. Anim. Sci. 21:428-432.

Chen, Y., J. J. Cheng, and K. S. Creamer. 2008. Inhibition of anaerobic digestion process: A review. Bioresour. Technol. 99:4044-4064.

Dean, D. B., C. R. Staples, R. C. Littell, S. C. Kim, and A. T. Adesogan. 2013. Effect of method of adding a fibrolytic enzyme to dairy cow diets on feed intake digestibility, milk production, ruminal fermentation, and blood metabolites. Anim. Nutr. Feed Technol. 13:287-302.

DuBois, M., K. A. Gilles, J. K. Hamilton, P. A. Rebers, and F. Smith. 1956. Colorimetric method for determination of sugars and related substances. Anal. Chem. 28:350-356.

Durand, M., and R. Kawashima. 1980. Influence of minerals in rumen microbial digestion. Pages 375-408 in Digestive Physiology and Metabolism in Ruminants. Y. Ruckebusch and P. Thivend, ed. Springer, Amsterdam, the Netherlands.

Eun, J. S., and K. A. Beauchemin. 2007. Enhancing in vitro degradation of alfalfa hay and corn silage using feed enzymes. J. Dairy Sci. 90:2839-2851.

Eun, J. S., K. A. Beauchemin, and H. Schulze. 2007. Use of exogenous fibrolytic enzymes to enhance in vitro fermentation of alfalfa hay and corn silage. J. Dairy Sci. 90:1440-1451.

Galyean, M. L. 2010. Laboratory procedures in animal nutrition research. Texas Tech University, Lubbock. Accessed Nov. 10, 2013. http://www.depts.ttu.edu/afs/home/mgalyean/lab_man.pdf.

Glass, N. L., M. Schmoll, J. H. D. Cate, and S. Coradetti. 2013. Plant cell wall deconstruction by Ascomycete fungi. Annu. Rev. Microbiol. 67:477-498.

Glusker, J. P. 2011. Encyclopedia of Inorganic and Bioinorganic Chemistry. John Wiley \& Sons Inc.. New York, NY.

Goering, H. K., and P. J. Van Soest. 1970. Forage fiber analysis (apparatus, reagents, procedures, and some applications). Agric. Handbook No. 379. USDA Agricultural Research Service, Washington, DC.

Harris, P. V., D. Welner, K. C. McFarland, E. Re, J.-C. Navarro Poulsen, K. Brown, R. Salbo, H. Ding, E. Vlasenko, S. Merino, F. $\mathrm{Xu}$, J. Cherry, S. Larsen, and L. Lo Leggio. 2010. Stimulation of lignocellulosic biomass hydrolysis by proteins of glycoside hydrolase family 61: Structure and function of a large, enigmatic family. Biochemistry 49:3305-3316.

Harrison, G. A., K. A. Dawson, and R. W. Hemken. 1992. Effects of high iron and sulfate ion concentrations on dry matter digestion and volatile fatty acid production by ruminal microorganisms. J. Anim. Sci. 70:1188-1194

Ishida, N., K. Takahashi, and R. Kawashima. 1988. Distribution of mineral components in the alimentary tract of sheep. Trace Nutrients Res. 4:155-162.

John, M., and J. Schmidt. 1988. Xylanases and $\beta$-xylosidase of Trichoderma lignorum. Methods Enzymol. 160:662-671.

Kanauchi, M., S. Watanabe, T. Tsukada, K. Atta, T. Kakuta, and T. Koizumi. 2008. Purification and characteristics of feruloyl esterase from Aspergillus awamori G-2 strain. J. Food Sci. 73:C458-463.

Krueger, N. A., and A. T. Adesogan. 2008. Effects of different mixtures of fibrolytic enzymes on digestion and fermentation of bahiagrass hay. Anim. Feed Sci. Technol. 145:84-94.

Krueger, N. A., A. T. Adesogan, C. R. Staples, W. K. Krueger, S. C Kim, R. C. Littell, and L. E. Sollenberger. 2008. Effect of method of applying fibrolytic enzymes or ammonia to bermudagrass hay on feed intake, digestion, and growth of beef steers. J. Anim. Sci. $86: 882-889$.

Lai, K. K., G. L. Lorca, and C. F. Gonzalez. 2009. Biochemical properties of two cinnamoyl esterases purified from Lactobacillus johnsonii strain isolated from stool samples of diabetes-resistant rats. Appl. Environ. Microbiol. 75:5018-5024.
Mackie, R. I., and J. J. Therion. 1984. Influence of mineral interactions on growth efficiency of rumen bacteria. Pages 456-477 in Herbivore Nutrition in the Subtropics and Tropics. F. M. C. Gilchrist and R. I. Mackie, eds. The Science Press, Craighall, South Africa.

Martinez, A., and D. C. Church. 1970. Effect of various mineral elements on in vitro rumen cellulose digestion. J. Anim. Sci. 31:982990.

McCrae, S. I., K. M. Leith, A. H. Gordon, and T. M. Wood. 1994. Xylan-degrading enzyme system produced by the fungus Aspergillus awamori: Isolation and characterization of a feruloyl esterase and a p-coumaroyl esterase. Enzyme Microb. Technol. 16:826-834.

Meale, S. J., K. A. Beauchemin, A. N. Hristov, A. V. Chaves, and T. A. McAllister. 2014. Opportunities and challenges in using exogenous enzymes to improve ruminant production. J. Anim. Sci. 92:427-442.

Mertens, D. R. 2003. Challenges in measuring insoluble dietary fiber J. Anim. Sci. 81:3233-3249.

Mertens, D. R. 2007. Digestibility and intake. Pages 487-508 in Forages: The Science of Grassland Agriculture. R. F. Barnes, C. J Nelson, K. J. Moore, and M. Collins, ed. Blackwell Publishing, Ames, IA.

Muck, R. E., and J. T. Dickerson. 1988. Storage temperature effects on proteolysis in alfalfa silage. Trans. ASAE 31:1005-1009.

Newman, Y. 2007. Costal vs. Tifton 85 Bermudagrass for Horses. Facts \& Myths. University of Florida, IFAS Extension. Accessed Apr. 16, 2015. http://cflag.ifas.ufl.edu/documents/2007EquineInstit/ CoastalvsT-85.pdf.

Nikolic, J. A., M. Jovanovic, R. Andric, and J. Krsmanovic. 1978. Influence of mineral element concentration on protein synthesis by rumen microorganisms in vitro. Acta Vet. (Beogr.) 28:57-66.

Noel, R. J., and L. G. Hambleton. 1976. Collaborative study of a sem automated method for determination of crude protein in animal feeds. J. Assoc. Off. Anal. Chem. 59:134-140.

Purich, D. L. 2011. Enzyme Kinetics. Catalysis \& Control: A Reference of Theory and Best-Practice Methods. Elsevier, London, UK.

Quinlan, R. J., M. D. Sweeney, L. L. Leggio, H. Otten, J.-C. N Poulsen, K. S. Johansen, K. B. R. M. Krogh, C. I. Jørgensen, M. Tovborg, A. Anthonsen, T. Tryfona, C. P. Walter, P. Dupree, F. Xu, G. J. Davies, and P. H. Walton. 2011. Insights into the oxidative degradation of cellulose by a copper metalloenzyme that exploits biomass components. Proc. Natl. Acad. Sci. USA 108:15079-15084

Riou, C., J. M. Salmon, M. J. Vallier, Z. Günata, and P. Barre. 1998. Purification, characterization, and substrate specificity of a novel highly glucose-tolerant $\beta$-glucosidase from Aspergillus oryzae. Appl. Environ. Microbiol. 64:3607-3614.

Romero, J. J., E. G. Macias, Z. X. Ma, R. M. Martins, B. Y. Coy, F. M. Silva, D. H. Garbuio, I. A. Brody, C. L. Curry, K. J. Mills, M. G. Zenobi, C. R. Staples, and A. T. Adesogan. 2014. Improving the performance of dairy cattle with a xylanase-rich exogenous enzyme preparation. J. Dairy Sci. 97(E-Suppl. 1):652. (Abstr)

Romero, J. J., M. A. Zarate, and A. T. Adesogan. 2015b. Effect of the dose of exogenous fibrolytic enzyme preparations on preingestive fiber hydrolysis, ruminal fermentation, and in vitro digestibility of bermudagrass haylage. J. Dairy Sci. 98:406-417.

Romero, J. J., M. A. Zarate, K. G. Arriola, C. F. Gonzalez, C. SilvaSanchez, and A. T. Adesogan. 2015a. Screening exogenous fibrolytic enzyme preparations for improved in vitro digestibility of bermudagrass haylage. J. Dairy Sci. 98:2555-2567.

Saad, R. R., and E. M. Fawzi. 2004. Purification and some properties of an extracellular 1,4- $\beta$-endoglucanase from Trichoderma longibrachiatum. New Egypt. J. Microbiol. 8:1-9.

Saha, B. C. 2003. Hemicellulose bioconversion. J. Ind. Microbiol. Biotechnol. 30:279-291.

Sang, S. L., G. Li, X. P. Hu, and Y. H. Liu. 2011. Molecular cloning, overexpression and characterization of a novel feruloyl esterase from a soil metagenomic library. J. Mol. Microbiol. Biotechnol. $20: 196-203$

SAS Institute. 2003. SAS/STAT 9.1 User's Guide. SAS Institute Inc., Cary, NC.

Schingoethe, D. J., G. A. Stegeman, and R. J. Treacher. 1999. Response of lactating dairy cows to a cellulase and xylanase enzyme 
mixture applied to forages at the time of feeding. J. Dairy Sci. 82:996-1003.

Singh, A., A. K. Agrawal, A. B. Abidi, and N. S. Darmwal. 1990. Properties of exoglucanase from Aspergillus niger. J. Gen. Appl. Microbiol. 36:245-253.

Tejirian, A., and F. Xu. 2010. Inhibition of cellulase-catalyzed lignocellulosic hydrolysis by iron and oxidative metal ions and complexes. Appl. Environ. Microbiol. 76:7673-7682.

Theander, O. 1995. Total dietary fiber determined as neutral sugar residues, uronic acid residues, and Klason lignin (the Uppsala method): Collaborative study. J. AOAC Int. 78:1030-1044.

Van Soest, P. J., J. B. Robertson, and B. A. Lewis. 1991. Methods for dietary fiber, neutral detergent fiber and non-starch polysaccharides in relation to animal nutrition. J. Dairy Sci. 74:3583-3597.

Voet, D., J. G. Voet, and C. W. Pratt. 2010. Fundamentals of Biochemistry. Upgrade ed. John Wiley \& Sons Inc., New York, NY.

Wetzel, R., and K. H. Menke. 1978. Behavior of trace elements copper, zinc, and manganese in bovine rumen, 1 . Trace element content of different fractions of rumen fluid and the effect of copper sulfate administration. Arch. Tierernahr. 28:221-233.

Wood, T. M., and K. M. Bhat. 1988. Methods for measuring cellulase activities. Pages 87-112 in Methods in Enzymology. W. A. Wood, and S. T. Kellogg, ed. Vol. 160. Academic Press. London, UK.

Zhang, Y. H. P., and L. R. Lynd. 2004. Toward and aggregated understanding of enzymatic hydrolysis of cellulose: Noncomplexed cellulose systems. Biotechnol. Bioeng. 88:797-824.

\section{APPENDIX}

\section{Effects of COF Addition to EFE on Additional Fermentation Indices in Experiment 2}

Manganese Addition to EFE 11C. Applying $11 \mathrm{C}$ alone increased the butyrate and valerate concentrations and decreased the $\mathrm{pH}$ (Table A1). Adding increasing doses of $\mathrm{Mn}^{2+}$ alone decreased ammonia-N $(P<0.01$, linear $)$ and valerate $(P<0.05$, quadratic $)$ concentrations and resulted in cubic fluctuations in isobutyrate concentrations. However, in the presence of $\mathrm{EFE} 11 \mathrm{C}$, no changes in isobutyrate or ammonia$\mathrm{N}$ were observed, but cubic fluctuations occurred for isovalerate and valerate $\left(\mathrm{EFE} \times \mathrm{Mn}^{2+}\right.$ dose interaction; $P<0.05)$.

Iron Addition to EFE $2 A$ and 13D. Adding $2 \mathrm{~A}$ alone increased butyrate, isobutyrate, isovalerate, and $\mathrm{pH}$ and decreased the ammonia- $\mathrm{N}$ concentration (Table $\mathrm{A} 2$ ), and 13D alone increased isobutyrate concentration and decreased ammonia-N (Table A3; $P<0.05$ ). Adding increasing doses of $\mathrm{Fe}^{2+}$ alone linearly increased $\mathrm{pH}(P<0.01)$ and decreased butyrate, isovalerate, and ammonia-N concentrations $(P<0.05$, cubic). Increasing the dose of the $\mathrm{Fe}^{2+}$ added to $2 \mathrm{~A}$ resulted in no changes on $\mathrm{pH}$, linear increases $(P<0.01)$ in valerate, a quadratic decrease $(P<0.01)$ in isobutyrate, and cubic effects $(P<0.05)$ on butyrate and ammonia$\mathrm{N}$ concentrations $\left(\mathrm{EFE} \times \mathrm{Fe}^{2+}\right.$ dose interaction; $P<$ 0.05). Adding increasing doses of $\mathrm{Fe}^{2+}$ to $13 \mathrm{D}$ did not affect isovalerate and decreased the butyrate concentration (linear, $P<0.05$ ) as well as the ammonia-N concentration (quadratic, $P<0.01$; $\mathrm{EFE} \times \mathrm{Fe}^{2+}$ dose interaction; $P<0.05)$.

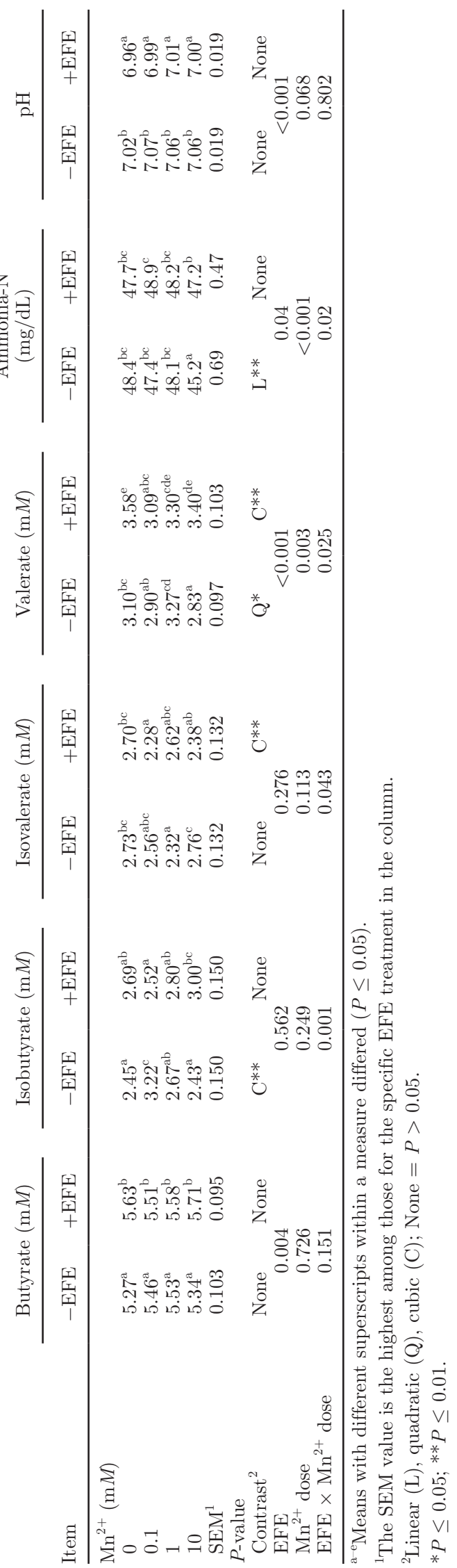

Journal of Dairy Science Vol. 98 No. 7, 2015 

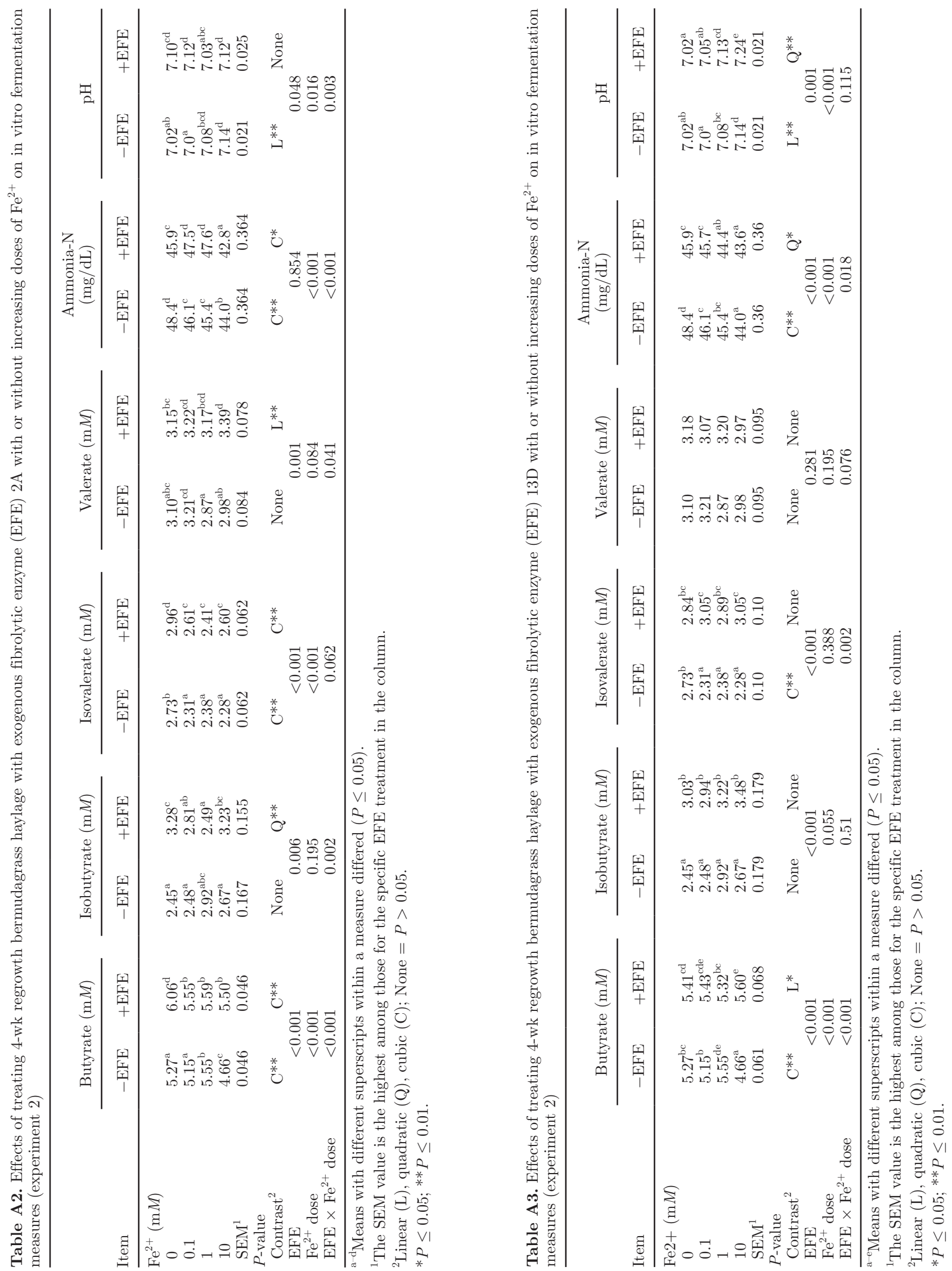